extraction, and may have been prehistorically connected, but the Chitráli calls himself Kho, and speaks "Khowar," and his language (ordinarily known as (hitráli) would not be understood in Wakhan. The Tajik (the original Persian stock) of Turkestan and the ()xus does not derive his designation from táj, " a crown," but from Tazi, a word which means "Arabic"-or "of Arab extraction," and which is more intelligible as applied by the pure bred Persian to the Tajik races of Baluchistan (where there has ever been much Arab admixture of blood) than to the people of the Oxus or of the Kabul basin. It practically means "half breed," and may be recognised again in the word Tazi, which Mr. Cobbold applies to the dogs which he brought with him from the highlands.

That the Hindu Kush may ultimately mark the geographical boundary between Russian and British spheres of interest in Asia, or even that Chinese Turkestan (or the New Dominion) may ultimately become as much a Russian province as Bokhara (and it certainly is a fact that Russian influence is already predominant in Kashgar), is an eventuality which many politicians have contemplated for years past. But it strikes no terror into the hearts of those who look upon a definite and final understanding with Russia as the best guarantee for peace and for the advancement of civilisation in Asia. Nor need we as yet concern ourselves with such a consummation as would be involved by the Cossacks gazing down on Kabul from their barracks "on the heights of the Kohistan."

Apart from his political views, Mr. Cobbold's book is instructive as well as interesting. He tells us much that is new about districts which are not within the reach of every traveller, and his chapter on the trade of Inner. most Asia is specially worth study.

T. H. H.

\section{IDR. WILLIAM MARCET, F.R.S.}

$A \mathrm{LL}$ who are interested in medicine and the cosnate sciences learnt with great regret of the death of I)r. William Marcet, which occurred on March 4, at Luxor, at the ripe age of seventy-two years. Dr. Marcet up till last summer continued to take that keen interest in matters scientific which had characterised him all his life, and it was only with a pronounced failure in his health that he discontinued active physiological research. His active scientific life in London was longer than the average, and exceeded half a century ; and this, perhaps, accounts for his many friends, and also for the fact that he was brought into contact with successive generations of physiological workers. His ample means rendered time of less consequence to him than to many of his colleagues, and this good fortune was utilised by him to the full, in that his researches were for the most part directed to themes of a time-consuming nature, and also to those requiring for their adequate prosecution somewhat elaborate and expensive methods.

With the exception of his contributions to meteorology, his work was almost entirely directed to the chemical side of physiology and pathology; his additions to the literature of clinical medicine were relatively small; and although he was for some time on the staff of the iVestminster and Brompton Hospitals, as a physician, he was by the present generation hardly known.

The first sphere of his chemico-physiological labours was a somewhat unæsthetic one-viz. the human fieces. In 185 I he published "Some observations on the fatty matters of human excrements in disease." In 1856 his first work upon dietetics appeared, entitled "The composition of food and how it is adulterated, with practical directions for its analysis." This book was one of the earliest systematic contributions to this subject, and must have been the expression of considerable labour and research. Dr. Marcet next directed his attention to the physioNO. I 586 , VOL. 6 I] logical and pathological properties of alcohol, and published two monographs upon the subject. His "Chronic alcoholic intoxication "includes a synoptical table of cases. In 1864 he made some observations upon a colloid acid, a normal constituent of human urine, and in the same year published a short essay upon the brine of salt meat and on the distribution of albumen through the muscular tissue. His dietetic researches extended, in 1867 , to a description of a method for peptonising meat, and the employment of the formed product in diseases of the stomach.

I)r. Marcet, in this country, was one of the earliest workers with the laryngoscope, and wrote, in 1869 , "Clinical notes on diseases of the larynx, investigated and treated with the assistance of the laryngoscope." In 1860 he published the results of some observations he made upon the temperature of the human body during climbing.

Dr. Marcet's two contributions to meteorology and climatology were a monograph on the weather at Cannes during the season $1875-76$, which appeared in 1877 , and a book of some four hundred pages on the "I'rincipal Southern and Swiss health resorts," which was published in 1883 . Although this book cannot be regarded as a systematic treatise on climatology, it is most readable, and contains a mass of useful hygienic: information concerning the Riviera, Canary Islands, Madeira, Egypt, \&c. Even a discussion of the cause of the green colour of Marennes oysters is to be found in it.

In spite of the somewhat extensive bibliography given above, it is nevertheless as a worker on respiration that the subject of this notice was, and will be, chiefly known. Years of researches upon this subject, both in London and at high altitudes, resulted in the appearance in 1897 of Dr. Marcet's "Contribution to the history of the respiration of man." The book consists essentially of the subject-mattcr of the Croonian I.ectures which were delivered by Dr. Marcet before the Royal College of Physicians in 1895 . As this book was fully reviewed in these columns at the time of its appearance, no further mention need be made of it here. Not only will physiology miss Dr. Marcet as a worker, but working physiologists will miss him as a personality; he was constantly to be seen at meetings of the Physiological Society, and kept up his interest in all the branches of that science which has extended so enormously the field of its knowledge since he joined the ranks of its workers.

F. W. TunNiclifie.

\section{SIR MICHAEL FOSTER ANI) IIIS PUPILS.}

$\mathrm{W}^{\mathrm{E}}$ have been asked to publish the following letter, addressed to Sir Michael Foster on the occasion of his entering Parliament. His biological friends at Cambridge have done well in expressing their loyalty towards Sir Michael, to whom the University owes so much. The signatures might doubtless have been indefinitely multiplied had the opportunity of adding their names been given to Sir Michael Foster's friends and pupils scattered over many lands. This, however, was not attempted, the letter not being circulated beyond the group of old pupils and friends, in Cambridge, with whom it originated.

To Sir Michaei, Foster, K.C. B., M.P.

Dear Sir Michafi, - We, a few of your Cambridge friends, take the opportunity given by your entering Parliament to express our loyalty, respect, and cordial friendship) towards you.

Though we regret anything which takes you from anong us, yet we cannot but rejoice that the cause of learning has gained so strong an advocate in Parliament.

The work you have done in Cambridge during the last thirty years seems to us of unique value. You have taught us to recog. nise what is worth learning, and you have taught us how to learn. If we, in Cambridge, now value and seek after the 